\title{
Effect of energy and protein supplementation on phosphorus utilization in lactating dairy cows*
}

\author{
E. Kebreab ${ }^{1,3}$, J. France ${ }^{1}$, J.D. Sutton ${ }^{2}$, L.A. Crompton ${ }^{2}$ \\ and D.E. Beever ${ }^{2}$ \\ ${ }^{I}$ Centre for Nutrition Modelling, Department of Animal and Poultry Science, University of Guelph \\ Guelph, Ontario N1G 2W1, Canada \\ ${ }^{2}$ School of Agriculture, Policy and Development, The University of Reading \\ Earley Gate, Reading RG6 6AR, United Kingdom
}

(Received 24 May 2004; revised version 12 November 2004; accepted 31 January 2005)

\begin{abstract}
Two experiments were undertaken in which grass silage was used in conjunction with a series of different concentrate types designed to examine the effect of carbohydrate source, protein level and degradability on total dietary phosphorus $(\mathrm{P})$ utilization with emphasis on $\mathrm{P}$ pollution. Twelve Holstein-Friesian dairy cows in early to mid-lactation were used in an incomplete changeover design with four periods consisting of 4 weeks each. Phosphorus intake ranged from 54 to $80 \mathrm{~g} /$ day and faecal $\mathrm{P}$ represented the principal route by which ingested $\mathrm{P}$ was disposed of by cows, with insignificant amounts being voided in urine. A positive linear relationship between faecal $\mathrm{P}$ and $\mathrm{P}$ intake was established. In Experiment 1, P utilization was affected by dietary carbohydrate type, with an associated output of $3.3 \mathrm{~g}$ faecal $\mathrm{P} / \mathrm{g}$ milk P produced for all treatments except those utilizing low degradable starch and low protein supplements, where a mean value of $2.8 \mathrm{~g}$ faecal $\mathrm{P} / \mathrm{g}$ milk $\mathrm{P}$ was observed. In Experiment 2, where two protein levels and three protein degradabilities were examined, the efficiency of $\mathrm{P}$ utilization for milk $\mathrm{P}$ production was not affected by either level or degradability of crude protein $(\mathrm{CP})$ but a significant reduction in faecal $\mathrm{P}$ excretion due to lower protein and $\mathrm{P}$ intake was observed. In general, $\mathrm{P}$ utilization in Experiment 2 was substantially improved compared to the Experiment 1, with an associated output of $1.8 \mathrm{~g}$ faecal $\mathrm{P} / \mathrm{g}$ milk P produced. The improved utilization of $\mathrm{P}$ in Experiment 2 could be due to lower $\mathrm{P}$ content of the diets offered and higher dry matter (DM) intake. For dairy cows weighing $600 \mathrm{~kg}$, consuming $17-18 \mathrm{~kg} \mathrm{DM} /$ day and producing about $25 \mathrm{~kg}$ milk, $\mathrm{P}$ excretion in faeces and hence $\mathrm{P}$ pollution to the environment might be minimized without compromising lactational performance by formulating diets to supply about $68 \mathrm{~g} \mathrm{P} /$ day, which is close to recent published recommended requirements for $\mathrm{P}$.
\end{abstract}

KEY WORDS: dairy cows, phosphorus metabolism, pollution, energy intake, protein supplements

\footnotetext{
* Supported by DEFRA (UK), WA0311

${ }^{3}$ Corresponding author: e-mail: ekebreab@uoguelph.ca
} 


\section{INTRODUCTION}

Phosphorus $(\mathrm{P})$ is a key mineral essential to nearly every aspect of metabolism in a dairy cow (NRC, 2001). Therefore, $P$ needs to be supplied in sufficient quantity to optimize animal performance. However, dairy cows use less than 40$45 \%$ of dietary P intake (Jongbloed and Valk, 1998), the rest is excreted mainly in faeces. Faecal excretion can lead to $\mathrm{P}$ accumulation and saturation in the soil and can filter into groundwater or remain in surface water (Tamminga, 1996), which is known to cause eutrophication (Johnston, 1996).

It is therefore desirable to formulate $\mathrm{P}$ rations according to the requirement of the animals and reduce $\mathrm{P}$ pollution by dairy cows without compromising lactational performance. Paucity of data in relation to P metabolism and different interpretations of what are available has lead to a variety of recommendations for $\mathrm{P}$ requirement of dairy cows by different national research committees (e.g., AFRC, 1991; GFE, 2001; NRC, 2001).

Within the recommended $\mathrm{P}$ intakes, information on the effects of sources and degradability of carbohydrate and protein on $\mathrm{P}$ utilization is scarce. Tamminga (1992) suggested that faecal and urinary losses can be reduced by minimizing the intake of $\mathrm{P}$ and $\mathrm{N}$ relative to energy and synchronizing the availability of $\mathrm{N}$ and energy in the rumen.

The objective of the present study is to examine phosphorus utilization in lactating dairy cows consuming grass silage based diets and to consider how nutritional strategies can be developed to improve the efficiency of P utilization without compromising animal performance. Thus two experiments were conducted to test the hypothesis that efficiency of $\mathrm{P}$ utilization in dairy cattle is affected by carbohydrate source, protein level and degradability, which might lead to reductions in dietary $\mathrm{P}$ intakes with concomitant reductions in $\mathrm{P}$ excretion.

\section{MATERIAL AND METHODS}

\section{Animals and diets}

The experiments were carried out at the Centre for Dairy Research (CEDAR) in the Department of Agriculture at the University of Reading. Six multiparous Holstein-Friesian dairy cows in early to mid-lactation from the main CEDAR herd were used in each experiment. The initial average body weight $(\mathrm{BW})$ of the cows was $584(\mathrm{SD}=74)$ and $620(\mathrm{SD}=56) \mathrm{kg}$ in Experiment 1 and 2, respectively. The rations comprised early first cut partially wilted perennial ryegrass silage (Lolium perenne) prepared without additive and fed with six concentrate feeds as 
treatments. The concentrates used in both experiments were pelleted and offered at $7 \mathrm{~kg}$ dry matter $(\mathrm{DM}) /(\mathrm{cow} \cdot$ day $)$ on top of grass silage $(10 \mathrm{~kg} \mathrm{DM} /[\mathrm{cow} \cdot \mathrm{day}])$ in two equal meals daily. The total amounts of silage and concentrates offered in each experiment were balanced to be iso-energetic with respect to metabolizable energy (ME) and based on a predicted dry matter intake (DMI) of $17 \mathrm{~kg} /$ (cow·day) (AFRC, 1993) with $600 \mathrm{~g} / \mathrm{kg}$ total intake (DM basis) derived from grass silage.

\section{Experiment 1}

Six concentrates (as treatments) were formulated with different carbohydrate sources to provide different rates or extents of carbohydrate availability in the rumen (Table 1). The treatments were designated according to the characteristics of the main component as follows: high NDF (HNDF), low degradability starch (LDS), high degradability starch (HDS) and soluble sugars (SS). These four supplements were formulated to contain $160 \mathrm{~g}$ crude protein $(\mathrm{CP}) / \mathrm{kg} \mathrm{DM}$, whilst a further two supplements were prepared from mixed carbohydrate sources to constitute a negative control (NEG) with low CP (105 g/ $/ \mathrm{kg} \mathrm{DM})$ and P $(3.5 \mathrm{~g} / \mathrm{kg} \mathrm{DM})$ and a positive control (POS) with high $\mathrm{CP}(186 \mathrm{~g} / \mathrm{kg} \mathrm{DM})$ and $\mathrm{P}(4.7 \mathrm{~g} / \mathrm{kg} \mathrm{DM})$.

\section{Experiment 2}

The concentrates (as treatments) were formulated to supply two levels of CP ( 210 and $290 \mathrm{~g} \mathrm{CP} / \mathrm{kg} \mathrm{DM}$ ) each with three protein degradabilities (Table 1). To achieve these specifications, the supplements were designed to contain different proportions of solvent soyabean meal containing high degradable CP replaced by low degradable source of protein (Sopralin), a commercial soyabean meal treated with formaldehyde (BP Nutrition SRL, UK), to provide three protein degradabilities (namely; High (H), Medium (M) and Low (L)) within each protein level.

Both experiments were planned as incomplete changeover designs each comprising 4 periods and 6 cows. Within each experimental period, wk 1 to 3 were used for dietary adaptation and to determine daily DMI and milk production. During wk 4 in Experiment 1 (sampling and $\mathrm{P}$ balance week), total faeces and urine were collected daily from each animal for $6 \mathrm{~d}$, in addition to measurements of feed intake, feed refusal and milk production. In Experiment 2, wk 4 was used to assess treatment differences in terms of DMI, milk production and milk composition and wk 5 for measurement of total $\mathrm{P}$ balance. Methods of collection and sampling (milk, faeces and urine) were as described by Sutton et al. (1997). Samples of feeds, faeces and urine were stored frozen and dried at $60^{\circ} \mathrm{C}$ as appropriate for subsequent analyses. 
峲

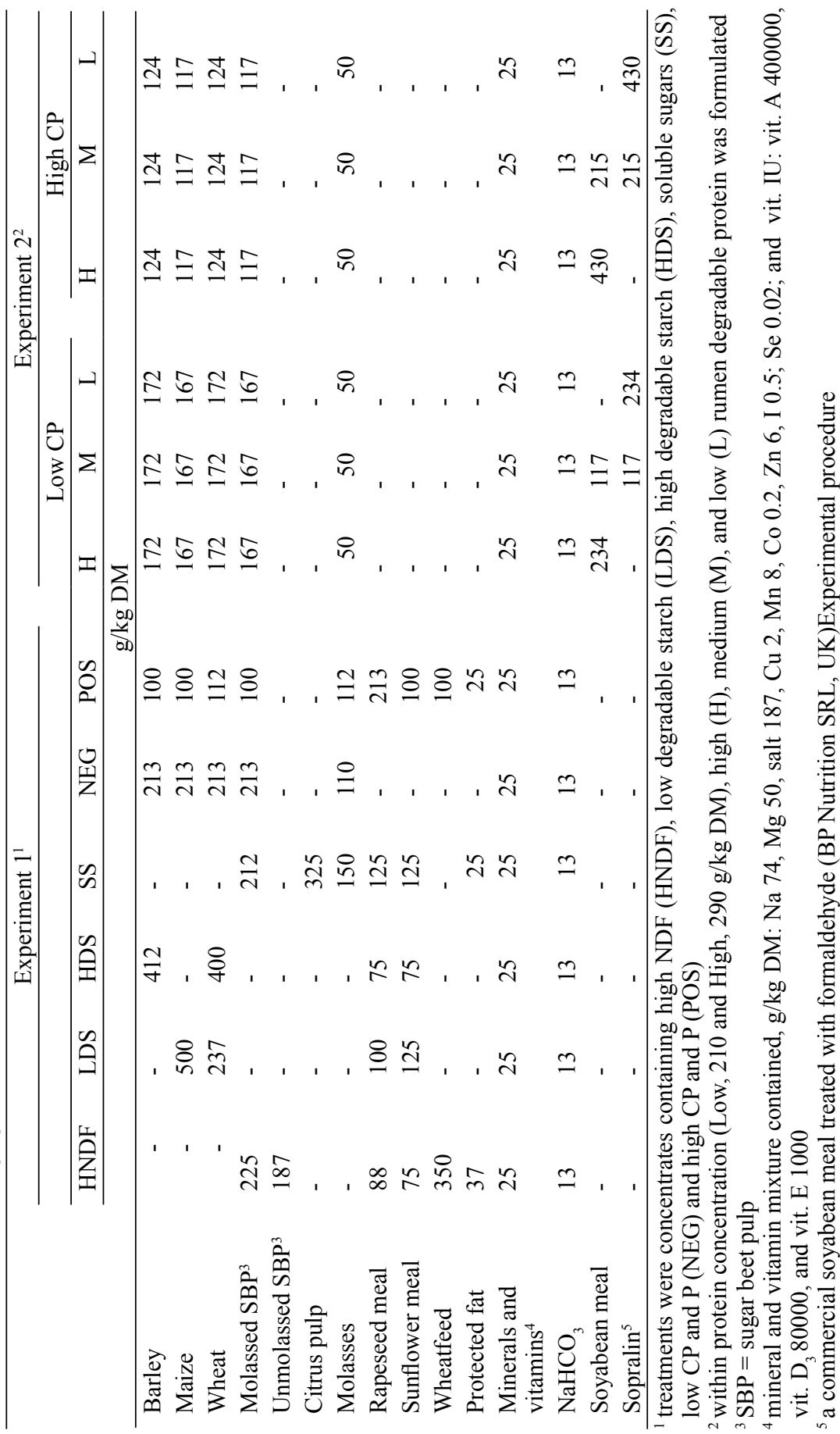


Dry matter and CP degradability of the experimental feeds was estimated using the in situ technique (Ørskov and McDonald, 1979). Effective degradability was calculated assuming a passage rate of $0.06 \mathrm{~h}^{-1}$ according to Sauvant and Archimede (1990; cited by Benchaar et al., 1998).

\section{Chemical analysis}

Silage corrected DM contents were based on oven DM content, corrected for the concentration of volatile components according to Porter et al. (1984). Neutral detergent fibre contents were determined by the method of Goering and Van Soest (1970), with amendments as proposed by Van Soest et al. (1991). For concentrate feeds, starch contents were determined by the enzymatic method of MacRae and Armstrong (1968). The water soluble carbohydrates (WSC) were extracted using distilled water and determined by the methods of Somogyi (1952) and Bailey et al. (1992).

For determination of $\mathrm{P}$ contents in feed and faeces, dried and finely ground samples $(0.5 \mathrm{~g})$ were weighed into $25 \mathrm{ml}$ glass beakers. The samples were then ashed initially with concentrated nitric acid followed by placing in a muffle furnace at $480^{\circ} \mathrm{C}$ overnight. The ash was taken up in $50 \%$ hydrochloric acid in a $50 \mathrm{ml}$ volumetric flask and volume was made up using distilled water. For milk P determinations, a homogenized milk sample $(2.0 \mathrm{~g})$ was weighed into a crucible and dried overnight in an oven at $105^{\circ} \mathrm{C}$. The samples were then gradually ashed $\left(+50^{\circ} \mathrm{C}\right.$ every $\left.30 \mathrm{~min}\right)$ up to $550^{\circ} \mathrm{C}$ and finally ashed for a further $2 \mathrm{~h}$. The ash was dissolved in $5 \mathrm{ml}$ mixture of distilled water, nitric acid and hydrochloric acid (4:1:3 by volume) and the samples were then gently heated on a hot plate $\left(105^{\circ} \mathrm{C}\right)$ for 10 min to re-dissolve the residue. The residue was filtered through Whatman number 1 filter paper in a $50 \mathrm{ml}$ volumetric flask and its volume made up with distilled water (Smoler, 1996). For urine P determinations, samples were thawed at room temperature and $30 \mathrm{~g}$ of each sample was weighed into $50 \mathrm{ml}$ glass beakers and gently heated on a hot plate until the volume was reduced to approximately $5-10 \mathrm{ml}$ (Morse et al., 1992). These samples were then dried in a hot air oven at $55^{\circ} \mathrm{C}$ for 16 $\mathrm{h}$ and ashed at $500^{\circ} \mathrm{C}$ for $4 \mathrm{~h}$, solubilized in $10 \mathrm{ml}$ of $3 \mathrm{~N}$ hydrochloric acid, filtered into a $25 \mathrm{ml}$ volumetric flasks and brought to volume with distilled water.

Total P content was then determined using an autoanalyser technique (WPA Heliflow, flow injection system, Cambridge, UK) with molybdenum blue. This method is based on the released $\mathrm{P}$ combining with ammonium molybdate in acid solution to produce phosphomolybdic acid. A blue colour (molybdenum blue) is produced in the solution when the phosphomolybdic acid is reduced following the addition of ascorbic acid with final estimation on a colorimeter at $680 \mathrm{~nm}$ wavelength. Protein, fat and lactose contents in milk were determined using infrared techniques (Foss Electric UK, Ltd.) with use of externally calibrated milk samples. 


\section{Statistical analysis}

Data were analysed statistically using the General Linear Models procedure of SAS (SAS, 2000) in Experiment 1, where the sources of variation were in the following order: periods, cows and treatments. The overall means obtained were adjusted means or least square means, which were assessed for significant differences at $\mathrm{P}<0.05$. In Experiment 2, the treatments were analysed as a $2 \times 3$ factorial arrangement, with 2 levels of protein, 3 levels of protein degradability. Because no interaction was detected $(\mathrm{P}<0.10)$, main effects of $\mathrm{CP}$ level were assessed by ANOVA, and the linear and quadratic effects of protein degradability averaged over CP level were assessed using orthogonal contrasts with single degrees of freedom.

\section{RESULTS}

\section{Feed composition}

Concentrate formulation and chemical composition of the diets are presented in Tables 1 and 2 . The grass silage in both experiments was relatively mature, with low $\mathrm{CP}$ and $\mathrm{P}$ concentrations. The diets were formulated to contain similar amount of P except in case of the NEG and POS treatments, which were formulated to contain much lower and higher values of $\mathrm{P}$, respectively. The desired $\mathrm{P}$ levels were achieved in the NEG and POS treatments, while in the other treatments P intake ranged from 65.7 to $77.7 \mathrm{~g} /$ day.

\section{Dry matter intake}

Total DMI in Experiment 1 ranged from 15.1 to $16.8 \mathrm{~kg}$ /day (averaged within a treatment). As expected, the NEG and POS controls had the lowest and the highest intakes, respectively. The NEG control reduced silage DMI by $16 \%$ compared to the POS control, and an average of $11 \%$ with respect to the different energy source treatments (HNDF, LDS, HDS and SS). In Experiment 2, DMI were higher, ranging from 17.2 to $18.3 \mathrm{~kg}$ /day with the extremes recorded for treatments with low and high levels of $\mathrm{CP}$, respectively.

\section{Milk P output and concentration}

In Experiment 1, milk P output averaged $17.1 \mathrm{~g} /$ day on all diets except in NEG where a fall in total milk yield was accompanied by a $15 \%$ reduction in $\mathrm{P}$ output compared to the average, which was significantly lower than for any of the other 
潀

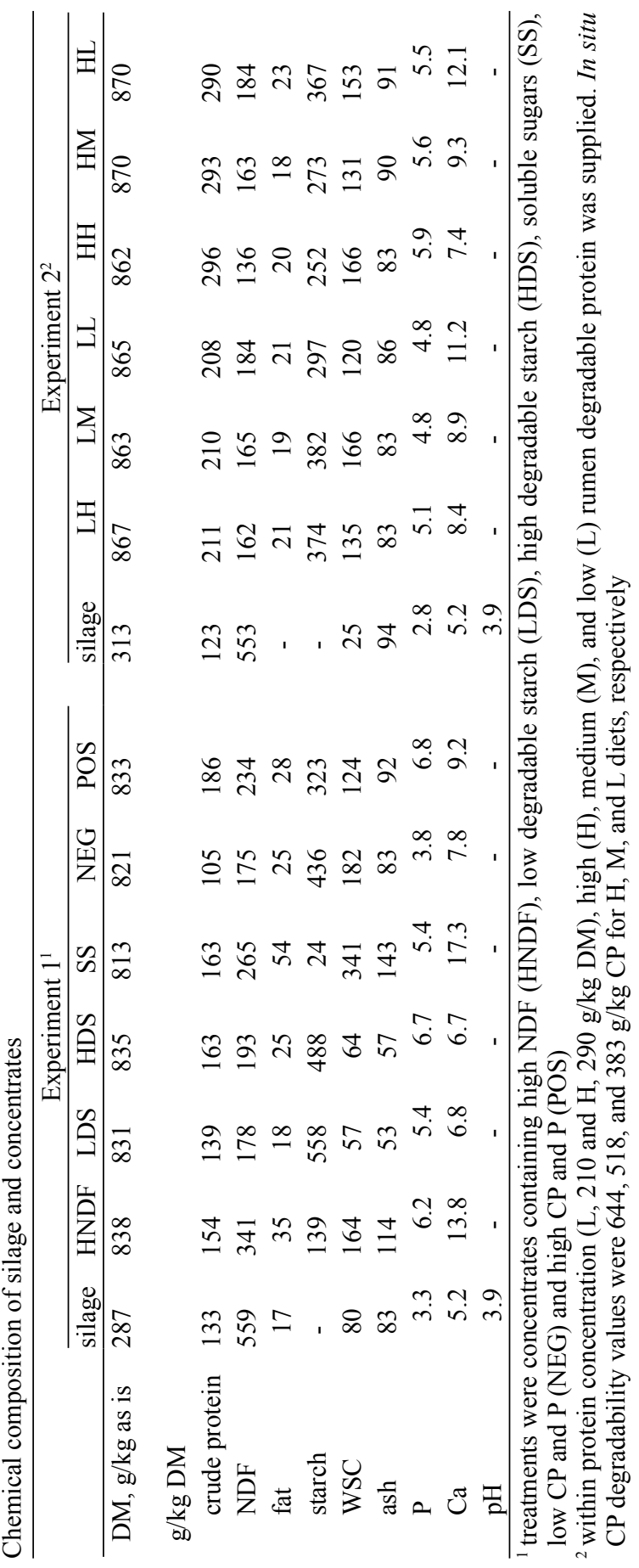


treatments. Cows on LDS and POS had the highest secretion of P in milk, which was significantly higher than SS but not HNDF and HDS (Table 3). In terms of

TABLE 3

Phosphorus $(\mathrm{P})$ balance and milk composition in Experiment 1

\begin{tabular}{|c|c|c|c|c|c|c|c|}
\hline & \multicolumn{6}{|c|}{ Treatments $^{1}$} & \multirow{2}{*}{ SEM } \\
\hline & HNDF & LDS & HDS & $\mathrm{SS}$ & NEG & POS & \\
\hline DMI, kg/day & $16.1^{y}$ & $16.0^{y}$ & $16.2^{\mathrm{y}}$ & $16.0^{y}$ & $15.1^{x}$ & $16.8^{y}$ & 0.23 \\
\hline Milk yield, kg/day & $20.7^{y}$ & $20.1^{\mathrm{y}}$ & $19.4^{y}$ & $19.4^{\mathrm{y}}$ & $16.6^{x}$ & $20.3^{y}$ & 0.54 \\
\hline P intake, g/day & $74.2^{\mathrm{y}}$ & $68.2^{\mathrm{x}}$ & $77.7^{\mathrm{z}}$ & $68.0^{\mathrm{x}}$ & $53.6^{\mathrm{w}}$ & $80.3^{z}$ & 0.95 \\
\hline \multicolumn{8}{|l|}{ P output, g/day } \\
\hline faeces & $56.9^{y}$ & $49.1^{x}$ & $57.2^{y}$ & $49.0^{\mathrm{x}}$ & $40.4^{\mathrm{w}}$ & $59.0^{\mathrm{y}}$ & 1.24 \\
\hline urine & 0.50 & 0.55 & 0.51 & 0.05 & 0.14 & 1.39 & 0.48 \\
\hline milk & $17.0^{\mathrm{xy}}$ & $17.7^{\mathrm{y}}$ & $17.2^{x y}$ & $16.2^{x}$ & $14.6^{\mathrm{w}}$ & $17.6^{\mathrm{y}}$ & 0.45 \\
\hline retained & -0.2 & 0.8 & 2.8 & 2.6 & -1.5 & 2.2 & 1.13 \\
\hline \multicolumn{8}{|c|}{$\mathrm{P}$ output, proportion of $\mathrm{P}$ intake } \\
\hline faeces & 0.76 & 0.72 & 0.74 & 0.72 & 0.75 & 0.74 & 0.017 \\
\hline urine & 0.006 & 0.008 & 0.007 & 0.001 & 0.003 & 0.017 & 0.006 \\
\hline milk & $0.23^{\mathrm{wx}}$ & $0.26^{x y}$ & $0.22^{\mathrm{wx}}$ & $0.24^{\mathrm{x}}$ & $0.27^{\mathrm{y}}$ & $0.21^{\mathrm{w}}$ & 0.007 \\
\hline \multicolumn{8}{|c|}{ Milk composition, g/day } \\
\hline protein & $30.0^{\mathrm{w}}$ & $33.0^{\mathrm{z}}$ & $32.8^{z}$ & $30.9^{\mathrm{x}}$ & $32.0^{y}$ & $33.0^{\mathrm{z}}$ & 0.16 \\
\hline $\mathrm{P}$ & $0.82^{\mathrm{w}}$ & $0.88^{\mathrm{x}}$ & $0.89^{\mathrm{x}}$ & $0.84^{\mathrm{wx}}$ & $0.88^{\mathrm{x}}$ & $0.87^{x}$ & 0.02 \\
\hline
\end{tabular}

${ }^{1}$ treatments were concentrates containing high NDF (HNDF), low degradable starch (LDS), high degradable starch (HDS), soluble sugars (SS), low CP and P (NEG) and high CP and P (POS)

${ }_{w, x, y, z}$ subcolumn means within row and treatment category with different superscripts differ $(\mathrm{P}<0.05)$

efficiency of P secretion in milk, LDS and NEG converted more dietary P to milk P (26 and 27\%). HNDF and SS treatments gave a lower protein and P concentration in milk compared to the other treatments. In Experiment 2, feeding high levels of protein did not affect milk $\mathrm{P}$ output $(\mathrm{P}=0.17)$ and concentration $(\mathrm{P}=0.19)$ despite a difference of $2.4 \mathrm{~g} /$ day and $0.05 \mathrm{~g} / \mathrm{kg}$, respectively (Table 4). Efficiency of dietary $\mathrm{P}$ conversion to milk $\mathrm{P}$ was not affected $(\mathrm{P}=0.31)$ by the treatments. Similarly, protein degradability had no significant effect on milk $\mathrm{P}$ output and concentration. Milk $\mathrm{P}$ output and concentration were on average higher by $6.5 \mathrm{~g} \mathrm{P} /$ day and $0.1 \mathrm{~g} / \mathrm{kg}$ milk, respectively, compared to Experiment 1 . The average efficiency of conversion of dietary $\mathrm{P}$ to milk $\mathrm{P}$ was $45 \%$ higher in Experiment 2 than in Experiment 1.

\section{Phosphorus balance}

Phosphorus balance data are presented in Tables 3 and 4. In Experiment 1, there were significant differences in P intakes, which ranged between 53.6 and 
憘

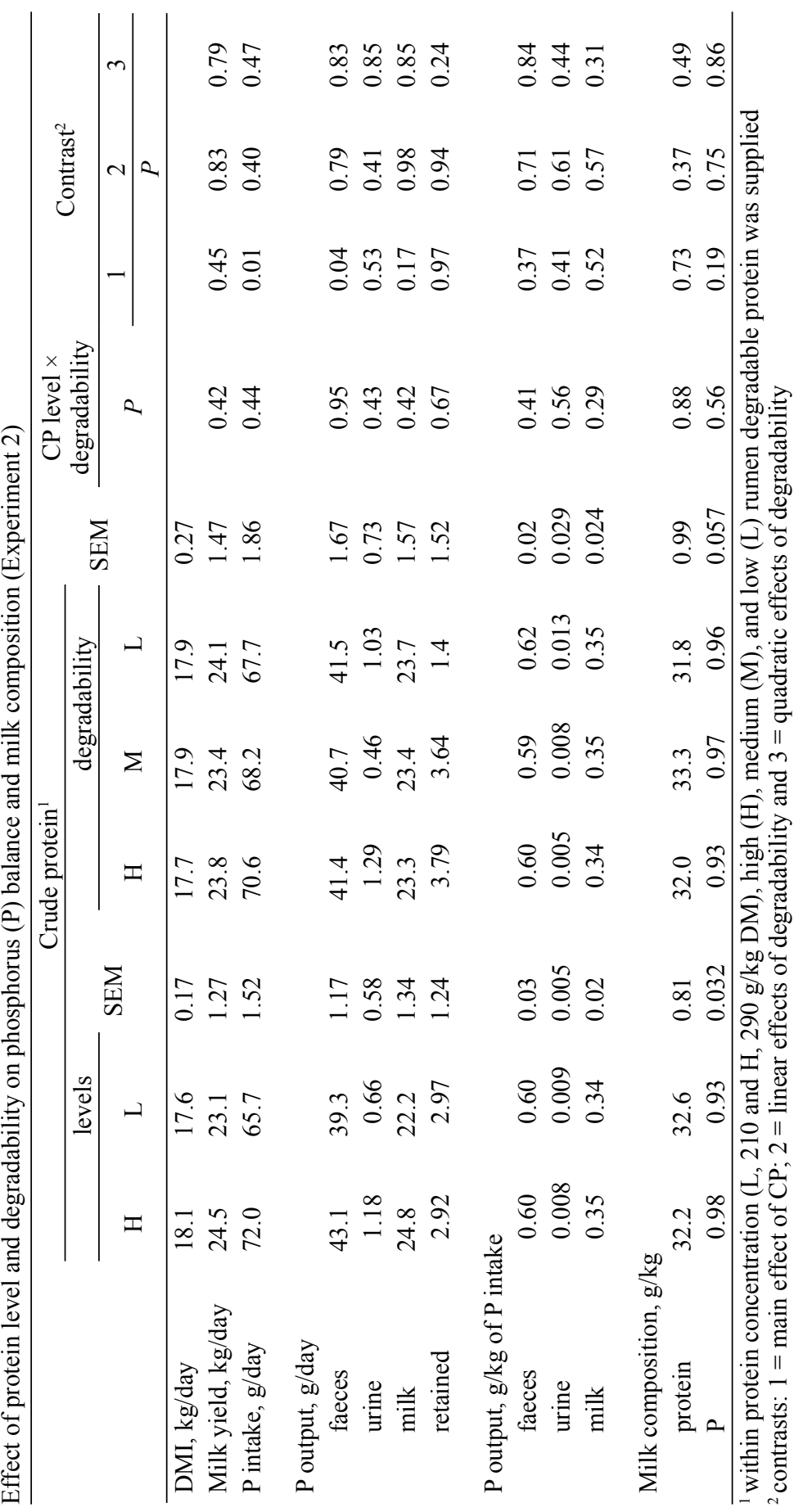


$80.3 \mathrm{~g} /$ day, being lowest and highest on the NEG and POS controls, respectively. Within the four carbohydrate types, LDS and SS had significantly lower P intakes, whilst the highest intake was observed on HDS $(\mathrm{P}<0.05)$. In Experiment 2, cows fed the lower protein level also had significantly lower P intakes (mean, 65.5 and $72.0 \mathrm{~g} /$ day for the lower and higher levels of CP, respectively). P intake was not significantly different in cows fed different $\mathrm{CP}$ degradabilities.

In Experiment 1, there were significant differences in the amount of $P$ excreted in faeces, where trends were similar to trends in P intake, with the NEG and POS treatments having the lowest and highest faecal $\mathrm{P}$ outputs, respectively. Similarly, in Experiment 2, more $\mathrm{P}$ was excreted in faeces by cows fed the higher $\mathrm{CP}$ level $(\mathrm{P}=0.04)$ but no effect of $\mathrm{CP}$ degradability was detected $(\mathrm{P}=0.79)$. In both experiments, urinary $P$ excretion ranged from $0.2-4.7 \mathrm{~g} / \mathrm{d}$ but was not significantly different among the treatments. Levels of P retention were also small and no consistent effects due to treatment could be detected in either experiment $(\mathrm{P}>0.05)$.

Faecal $\mathrm{P}$ accounted for the largest single proportion of $\mathrm{P}$ intake and there were no significant differences due to type of energy source, level of $\mathrm{P}$ intake, or level and degradability of CP. However, average $\mathrm{P}$ in faeces was higher in Experiment 1 (mean, 0.74 vs $0.60 \mathrm{~g} / \mathrm{g}$ P intake in Experiment 2). Urinary P represented less than $2 \mathrm{~g} / 100 \mathrm{~g} P$ intake in both experiments, and was not affected by the treatments imposed $(\mathrm{P}<0.05)$.

\section{DISCUSSION}

The objective of the present study was to assess the effects of energy and protein supplementation on $\mathrm{P}$ utilization by dairy cows in order to consider options for reducing $\mathrm{P}$ pollution without significantly reducing animal performance. Although dietary $\mathrm{P}$ intake was intended to be similar across treatments (except in NEG and POS), P intake in Experiment 1 ranged from 56 to $83 \mathrm{~g} /$ day, which approximately covers the range of $\mathrm{P}$ requirements recommended by the British (ARC, 1980; AFRC, 1991), French (INRA, 1989), and American (NRC, 2001) national research committees for the type of dairy cows used in our experiments and at the lower end of the German (GfE, 2001) national recommendations. In Experiment 2, P intake was restricted to 65-72 g/day, the higher end of which approximately corresponds to AFRC (1991) recommendations. The dietary Ca:P ratio varied between 1:1 and 3:1 between treatments. This level of variation is not expected to affect $\mathrm{P}$ metabolism as ruminants with an adequate supply of $\mathrm{P}$ can tolerate wide ranges of dietary $\mathrm{Ca}: \mathrm{P}$ ratios, with optimums between $1: 1$ and 7:1 (McDowell, 1992). 


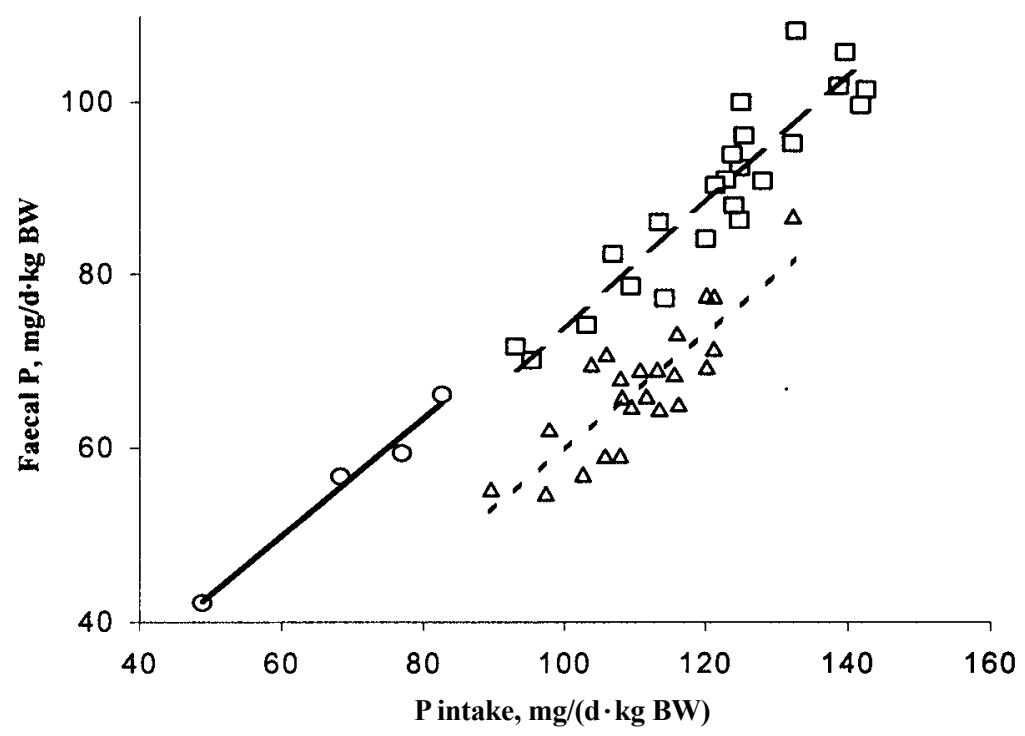

Figure 1. Relationship between P intake (PI, mg/[day $\cdot \mathrm{kg}$ body weight]) and faecal P (FP, mg/[day·kg body weight]) in lactating ewes (O) (data from Braithwaite, 1986) and dairy cows in Experiments $1(\square)$ and $2(\Delta)$. The fitted lines were as follows: FP in ewes $=9.4+0.68(\mathrm{PI})$ (SE $=4.88$ and 0.07 for the intercept and slope, respectively; $\left.\mathrm{r}^{2}=0.98\right)$, FP in cows in Experiment $1=2.1+0.72(\mathrm{PI})$ $\left(\mathrm{SE}=7.81\right.$ and 0.07 for the intercept and slope, respectively; $\left.\mathrm{r}^{2}=0.84\right)$ and FP in cows in Experiment $2=-8.3+0.68(\mathrm{PI})\left(\mathrm{SE}=6.58\right.$ and 0.06 for the intercept and slope, respectively; $\left.\mathrm{r}^{2}=0.71\right)$

Faecal P output was large in both experiments, which was similar to previous reports (e.g., Braithwaite, 1986 for lactating ewes; Morse et al., 1988 for lactating dairy cows) and it was directly related to $\mathrm{P}$ intake (Figure 1). The increase in faecal $\mathrm{P}$ output in response to increased $\mathrm{P}$ intake may be due to homeostasis and a result of an obligatory increase in unabsorbed endogenous and dietary P (Challa and Braithwaite, 1988a). The lack of significant difference in faecal $\mathrm{P}$ output when expressed as the proportion of $\mathrm{P}$ intake further confirms the positive linear relationship between the two variables. However, in Experiment 2 faecal P output represented $0.60 \mathrm{~g} / \mathrm{g}$ P intake, which was $0.14 \mathrm{~g} / \mathrm{g}$ P intake lower than in Experiment 1. This is possibly due to a combination of different factors, one of which may be the lower dietary P content (average $3.73 \mathrm{~g} / \mathrm{kg} \mathrm{DM}$ ) in Experiment 2 compared with Experiment 1 (average $4.26 \mathrm{~g} / \mathrm{kg} \mathrm{DM}$ ). The results agree with $\mathrm{Wu}$ et al. (2000) who reported that cows fed lower P $(4.0 \mathrm{~g} / \mathrm{kg}$ DM vs $4.9 \mathrm{~g} / \mathrm{kg}$ $\mathrm{DM}$ ) excreted $23 \%$ less in faeces and indicated that dairy cows conserve $\mathrm{P}$ by minimizing faecal and urinary $\mathrm{P}$ excretions if fed lower P diets. Differences in milk yield (average 19.3 and $23.8 \mathrm{~kg}$ /day in Experiment 1 and 2, respectively) could also have contributed to differences in faecal P output. Furthermore DMI was higher in Experiment 2, providing an ME intake of at least $30 \mathrm{MJ}$ more than in Experiment 1, 
which might have increased the efficiency of utilization of $\mathrm{P}$ by using some of the $\mathrm{P}$ that would have been excreted for milk, metabolism and body retention.

Urinary P outputs were negligible in accordance with previous reports (e.g., Vitti et al., 2000). There is some evidence that urinary excretion of $P$ is related to serum $P$ concentration and significant amounts are excreted only when the plasma $\mathrm{P}$ concentration exceeds a threshold, which in growing calves was about 2.3 mmol/l (Challa and Braithwaite, 1988b; Challa et al., 1989).

Milk P output was not linearly related to $\mathrm{P}$ intake, which suggests that some treatments might have provided a better efficiency of $\mathrm{P}$ utilization for milk. In Experiment 1, cows on the NEG treatment excreted substantially less $\mathrm{P}$ in milk than any of the other treatments. Increasing $P$ intake above $68 \mathrm{~g} /$ day resulted in a significant increase in faecal $\mathrm{P}$ output without an improvement in lactational performance. Although SS and LDS had similar P intakes and faecal P outputs, the latter had significantly higher milk output and tended to have higher milk $\mathrm{P}$ as a proportion of $P$ intake. This could be related to the way in which energy is made available in the rumen. Low degradable starch sources such as maize are known to improve $\mathrm{N}$ capture by microbes (Kebreab et al., 2000; Castillo et al., 2001), which in turn could increase $\mathrm{P}$ utilization. The correspondingly higher values of $\mathrm{P}$ and protein concentrations in milk further supports the premise that the efficiency of $\mathrm{N}$ utilization for milk production has an influence on $\mathrm{P}$ utilization. Experiment 2 showed that reducing dietary P intake from 72 to $66 \mathrm{~g} /$ day did not affect milk $\mathrm{P}$ output significantly. Although the overall efficiency of $\mathrm{P}$ utilization for milk production was still low, it was improved substantially in Experiment 2.

Valk and Šebek (1999) reported that $2.8 \mathrm{~g} \mathrm{P} / \mathrm{kg}$ DM was adequate for highyielding dairy cows (9000 1/[lactation·cow]), supplying $68 \mathrm{~g}$ P/day in early-mid lactation. Considering the DMI and milk output (7000 1/[lactation.cow]) in the present study, this value is lower than suggested by our work. This could be due to the higher energy concentration of the feed given by Valk and Šebek (1999), which might have increased the efficiency of P utilization. It may also be the case that the availability of about $70 \mathrm{~g} \mathrm{P} /$ day is the upper limit above which cows do not utilize more $\mathrm{P}$ regardless of milk output. Unfortunately, the authors did not report faecal $\mathrm{P}$ to support the theory of increased P utilization. Brodison et al. (1989) reported no significant effects of $\mathrm{P}$ utilization in cows consuming 'low' (52-63 g P/day) and 'high' (68-76 g P/day) amounts of P. Direct comparison with the results of this study is difficult because of differences in DMI and in milk production of $2000 \mathrm{l} / \mathrm{yr}$. However, considering the lower demand of $\mathrm{P}$ associated with a lower milk yield, it is expected that the requirements of those cows to be not more than 52 to $63 \mathrm{~g} \mathrm{P} /$ day.

Overall there were no consistent effects attributable to dietary protein degradability, suggesting that this is not a means by which $\mathrm{P}$ excretion can be manipulated in dairy cows. 
Currently, feed formulations include $\mathrm{P}$ in excess of the AFRC (1991) recommendations ( $74 \mathrm{~g} \mathrm{P} /$ day for the type of cows used in the experiments) due to feed companies adding excessive 'safety margins'. This has created environmental concerns about $\mathrm{P}$ pollution by dairy cows. The present study shows that the AFRC (1991) recommendation could be cut further by $10 \%$ without compromising lactational performance. Wu et al. (2001) showed that over two to three lactations feeding $\mathrm{P}$ high yielding cows at $0.31 \%$ of dietary DM appeared to decrease $\mathrm{P}$ concentration of bone, but the decrease was not severe enough to affect bone strength. Data from our experiments suggest that the optimum P requirement is about $68 \mathrm{~g} /$ day for cows consuming 17-18 $\mathrm{kg} \mathrm{DM} /$ day and producing $25 \mathrm{~kg}$ milk/day with possible improvement if the supplement to grass silage contains energy sources with a low degradable starch content. In a two-year study, Wu and Satter (2000) reported that reducing dietary P from 4.8 to $3.8 \mathrm{~g} / \mathrm{kg} \mathrm{DM}$ (supplying $68.4 \mathrm{~g}$ P assuming $18 \mathrm{~kg} \mathrm{DMI}$ ), did not impair milk production or reproductive performance of dairy cows.

In conclusion, environmental concerns about $\mathrm{P}$ pollution by dairy cows have led to investigation of the possibilities of reducing $\mathrm{P}$ excretion by means of dietary manipulation. If the reductions in $\mathrm{P}$ excretion noted for cows fed low degradable starch based supplements could be confirmed, it would represent a potential reduction in faecal $\mathrm{P}$ excretion from 1.15 to 0.98 tonnes for 100 cows yielding 4000 1/cow over a $180 \mathrm{~d}$ winter, an overall decline of $15 \%$. A $600 \mathrm{~kg}$ cow producing $251 \mathrm{milk} /$ day requires about $67 \mathrm{~g} \mathrm{P} /$ day for an optimal ratio of $\mathrm{P}$ output in faeces per unit of milk P. Increasing P intake above this value, decreases $\mathrm{P}$ utilization by the cow and leads to excretion of excess $P$ in faeces. Recommended values for $\mathrm{P}$ requirements by various national research committees are around 70$74 \mathrm{~g} \mathrm{P} /$ day for the type of cow used in the experiments reported herein and need to be regarded as the highest levels of inclusion when formulating diets for lactating dairy cows, in order to reduce environmental pollution.

\section{REFERENCES}

AFRC, 1991. A reappraisal of the calcium and phosphorus requirements of sheep and cattle. Nutr. Abstr. Rev., Ser. B 61, 573-612

AFRC, 1993. Energy and Protein Requirements of Ruminants. CAB International, Wallingford (UK)

ARC, 1980. The Nutrient Requirement of Ruminant Livestock. Commonwealth Agricultural Bureau, Slough (UK)

Bailey M.J., Biely P., Poutanen K., 1992. Interlaboratory testing of methods for assay of xylanase activity. J. Biotechnol. 23, 257-270

Benchaar C., Rivest J., Pomar C., Chiquette J., 1998. Prediction of methane production from dairy cows using existing mechanistic models and regression equations. J. Anim. Sci. 76, 617-627 
Braithwaite G.D., 1986. Phosphorus requirements of ewes in pregnancy and lactation. J. Agr. Sci. $106,271-278$

Brodison J., Goodall E.A., Armstrong J.D., Givens D.I., Gordon F.J., McCaughey W.J., Todd J.R., 1989. Influence of dietary phosphorus on the performance of lactating dairy cattle. J. Agr. Sci. $112,303-311$

Castillo A.R., Kebreab E., Beever D.E., Barbi J.H., Sutton J.D., Kirby H.C., France J., 2001. The effect of energy supplementation on nitrogen utilisation in grass silage diets by lactating dairy cows. J. Anim. Sci. 79, 240-246

Challa J., Braithwaite G.D., 1988a. Phosphorus and calcium metabolism in growing calves with special emphasis on phosphorus homeostasis 1 . Studies of the effect of changes in the dietary phosphorus intake on phosphorus and calcium metabolism. J. Agr. Sci. 110, 573-581

Challa J., Braithwaite G.D., 1988b. Phosphorus and calcium metabolism in growing calves with special emphasis on phosphorus homeostasis 3. Studies of the effect of continuous intravenous infusion of different levels of phosphorus in ruminating calves receiving adequate dietary phosphorus. J. Agr. Sci. 110, 591-595

Challa J., Braithwaite G.D., Dhanoa M.S., 1989. Phosphorus homeostasis in growing calves. J. Agr. Sci. 112, 217-226

GfE (Ausschuss für Bedarfsnormen der Gesellschaft für Ernährungsphysiologie), 2001. Empfehlungen zur Energie- und Nährstoffversorgung der Milchkühe und Aufzuchtrinder. DLG-Verlag, Frankfurt/Main (Germany)

Goering H.K., Van Soest P.J., 1970. Forage Fiber Analysis (Apparatus, Reagents, Procedures and some Applications). Agric. Handbook No. 379. ARS, USDA, Washington, DC

INRA (Institut National de la Recherche Agronomique), 1989. Ruminant Nutrition: Recommended Allowances and Feed Tables. R. Jarrige (Editor). INRA, Paris (France)

Johnston A.E., 1996. The efficient use of plant nutrients in agriculture. International Fertiliser Industry Association. Paris (France)

Jongbloed A.W., Valk H., 1998. Intensive animal production and environmental aspects with special reference to phosphorus. In: Production Diseases in Farm Animals. $10^{\text {th }}$ International Conference. Wageningen Press, Wageningen (The Netherlands), pp. 282-285

Kebreab E., Castillo A.R., Beever D.E., Humphries D.J., France J., 2000. The effects of management practices prior to and during ensiling and concentrate type on nitrogen utilisation and pollution in lactating dairy cows. J. Dairy Sci. 83, 1274-1285

MacRae J.C., Armstrong D.G., 1968. Enzyme method for determination of $\alpha$-linked glucose polymers in biological materials. J. Sci. Food Agr. 19, 578-581

McDowell L.R., 1992. Minerals in Animal and Human Nutrition. Academic Press, Inc., San Diego, CA (USA)

Morse D., Head H.H., Hissem C.D., Harris Jr. B., Van Horn H.H., 1988. Effects of phosphorus intake on excretion of faecal phosphorus. J. Dairy Sci. 71, Suppl. 1, 156

Morse D., Head H.H., Wilcox C.J., 1992. Disappearance of phosphorus in phytate from concentrates in vitro and from rations fed to lactating dairy cows. J. Dairy Sci. 75, 1979-1986

NRC, 2001. Nutrient Requirements of Dairy Cattle. $7^{\text {th }}$ revised Edition. National Academic Press. Washington, DC

Ørskov E.R., McDonald I., 1979. The estimation of protein degradability in the rumen from incubation measurements weighted according to rate of passage. J. Agr. Sci. 92, 499-503

Porter M.G., Patterson D.C., Steen R.W.J., Gordon F.J., 1984. Determination of dry matter and gross energy of grass silage. In: Proceedings of 7th Silage Conference. The Queen's University, Belfast (UK). Summary of Papers, Paper No. 45

SAS Inst. Inc., 2000. SAS/STAT User's Guide, Version 8 Edition. Cary, NC

Sauvant D., Archimède H., 1990. The prediction of the digesta passage rate in ruminants. Internal note. Laboratory INRA-INAPG (France) 
Smoler E., 1996. Mathematical models to predict milk protein concentration from dietary components fed to dairy cows. PhD. Thesis, The University of Reading (UK)

Somogyi M., 1952. Notes on sugar determination. J. Biol. Chem. 195, 10-23

Sutton J.D., Abdalla A.L., Phipps R.H., Cammell S.B., Humphries D.J., 1997. The effect of the replacement of grass silage by increasing proportions of urea-treated whole-crop wheat on food intake and digestibility and milk production by dairy cows. Anim. Sci. 65, 343-351

Tamminga S., 1992. Nutrition management of dairy cows as a contribution to pollution control. J. Dairy Sci. 75, 345-357

Tamminga S., 1996. A review on environmental impacts of nutritional strategies in ruminants. J. Anim. Sci. 74, 3112-3124

Valk H., Šebek L.B.J., 1999. Influence of long-term feeding of limited amounts of phosphorus on dry matter intake, milk production, and body weight of dairy cows. J. Dairy Sci. 82, 2157-2163

Van Soest P.J., Robertson J.B., Lewis B.A., 1991. Methods for dietary fiber, neutral detergent fiber, and nonstarch polysaccharides in relation to animal nutrition. J. Dairy Sci. 74, 3583-3597

Vitti D.M.S.S., Kebreab E., Lopes J.B., Abdalla A.L., De Carvalho F.F.R., De Resende K.T., Crompton L.A., France J., 2000. A kinetic model of phosphorus metabolism in growing goats. J. Anim. Sci. 78, 2706-2712

Wu Z., Satter L.D., 2000. Milk production and reproductive performance of dairy cows fed two concentrations of phosphorus for two years. J. Dairy Sci. 83, 1052-1063

Wu Z., Satter L.D., Sojo R., 2000. Milk production, reproductive performance, and fecal excretion of phosphorus by dairy cows fed three amounts of phosphorus. J. Dairy Sci. 83, 1028-1041

\section{STRESZCZENIE}

\section{Wpływ dodatku energii i białka na wykorzystanie fosforu przez dojne krowy}

W dwóch doświadczeniach przeprowadzonych na dojnych krowach, żywionych kiszonką z traw i różnego rodzaju paszami treściwymi, badano wpływ źródła węglowodanów, poziomu białka i jego degradacji w żwaczu na wykorzystanie fosforu ogólnego diety z uwzględnieniem zatruwania środowiska fosforem. Doświadczenia przeprowadzono na 12 dojnych krowach holsztyno-fryzach w okresie od wczesnej do połowy laktacji w układzie niekomletnym przemiennym w czterech okresach po 4 tygodnie każdy. Pobranie fosforu (P) wynosiło od 54 do $80 \mathrm{~g} /$ dzień. P był wydalany głównie z kałem, w moczu tylko nieznaczna jego ilość. Stwierdzono dodatnią liniową zależność między ilością fosforu pobranego $\mathrm{z}$ paszą a wydalonego $\mathrm{z}$ kałem. W doświadczeniu 1 stwierdzono, że na wykorzystanie fosforu miał wpływ rodzaj węglowodanów w diecie; ilość P wydalonego w kale wynosiła 3,3 g/g P zawartego w mleku we wszystkich układach doświadczalnych, z wyjątkiem dawek zawierających skrobię o niskim stopniu rozkładalności i o małej zawartości białka; w tych przypadkach krowy wydalały w kale średnio $2,8 \mathrm{~g}$ P/g P w mleku. W doświadczeniu 2, w którym skarmiano dawki o dwóch poziomach białka i trzech poziomach białka o różnym stopniu rozkładu w żwaczu, wykorzystanie fosforu na produkcję mleka nie zależało od stopnia rozkładu białka ogólnego $\mathrm{w}$ żwaczu, natomiast przy mniejszym pobraniu białka $\mathrm{z}$ paszą wydalanie $\mathrm{P} \mathrm{w}$ kale było istotnie mniejsze. Wykorzystanie fosforu $\mathrm{w}$ doświadczeniu 2 było większe niż $\mathrm{w}$ doświadczeniu 1 , krowy wydalały bowiem w kale $1,8 \mathrm{~g} \mathrm{P} / \mathrm{g}$ P w mleku. Lepsze wykorzystanie fosforu w doświadczeniu 2 mogło być spowodowane mniejszą zawartością fosforu w dietach i większym pobraniem suchej masy. U $600 \mathrm{~kg}$ krów, pobierających $17-18 \mathrm{~kg}$ s.m./dzień i produkujących około $25 \mathrm{~kg}$ mleka, wydalanie fosforu w kale i zanieczyszczanie nim środowiska może być zmniejszone bez uszczerbku dla wydajności mleka przez ułożenie dawki zawierającej około $68 \mathrm{~g}$ fosforu, co jest wartością zbliżoną do zapotrzebowania na fosfor zalecanego w większości publikacji. 
